\title{
Inhibition of HIV-I entry by extracts derived from traditional Chinese medicinal herbal plants
} In-Woo Park ${ }^{1,2}$, Changri Han ${ }^{3}$, Xiaoping Song 3 , Linden A Green ${ }^{1}$, Ting Wang ${ }^{1}$, Ying Liu ${ }^{1}$, Changchun Cen ${ }^{3}$, Xinming Song ${ }^{3}$, Biao Yang ${ }^{3}$, Guangying Chen*3 and Johnny J He*1,2

Address: ${ }^{1}$ Department of Microbiology and Immunology, Indiana University School of Medicine, Indianapolis, IN 46202 , USA, ${ }^{2}$ Center for AIDS Research, Indiana University School of Medicine, Indianapolis, IN 46202, USA and ${ }^{3}$ Department of Chemistry, Hainan Normal University, Haikou 571158, PR China

Email: In-Woo Park - parki@iupui.edu; Changri Han - hchr116@hainan.edu.cn; Xiaoping Song - sxp628@126.com;

Linden A Green - lhorten@indiana.edu; Ting Wang - wangt@iupui.edu; Ying Liu - yliu2@iupui.edu; Changchun Cen - cenchch321@163.com; Xinming Song - sxm8646@163.com; Biao Yang - yangbiao19850211@163.com; Guangying Chen* - chgying123@163.com;

Johnny J He* - jjhe@iupui.edu

* Corresponding authors

Published: 5 August 2009

BMC Complementary and Alternative Medicine 2009, 9:29 doi:10.1 186/1472-6882-9-29
Received: 19 June 2009

Accepted: 5 August 2009

This article is available from: http://www.biomedcentral.com/1472-6882/9/29

(C) 2009 Park et al; licensee BioMed Central Ltd.

This is an Open Access article distributed under the terms of the Creative Commons Attribution License (http://creativecommons.org/licenses/by/2.0), which permits unrestricted use, distribution, and reproduction in any medium, provided the original work is properly cited.

\footnotetext{
Abstract

Background: Highly active anti-retroviral therapy (HAART) is the current HIVIAIDS treatment modality. Despite the fact that HAART is very effective in suppressing HIV-I replication and reducing the mortality of HIV/AIDS patients, it has become increasingly clear that HAART does not offer an ultimate cure to HIV/ AIDS. The high cost of the HAART regimen has impeded its delivery to over $90 \%$ of the HIVIAIDS population in the world. This reality has urgently called for the need to develop inexpensive alternative anti-HIV/AIDS therapy. This need has further manifested by recent clinical trial failures in anti-HIV-I vaccines and microbicides. In the current study, we characterized a panel of extracts of traditional Chinese medicinal herbal plants for their activities against HIV-I replication.

Methods: Crude and fractionated extracts were prepared from various parts of nine traditional Chinese medicinal herbal plants in Hainan Island, China. These extracts were first screened for their anti-HIV activity and cytotoxicity in human CD4+ Jurkat cells. Then, a single-round pseudotyped HIV-luciferase reporter virus system (HIV-Luc) was used to identify potential anti-HIV mechanisms of these extracts.

Results: Two extracts, one from Euphorbiaceae, Trigonostema xyphophylloides (TXE) and one from Dipterocarpaceae, Vatica astrotricha (VAD) inhibited HIV-I replication and syncytia formation in CD4+ Jurkat cells, and had little adverse effects on host cell proliferation and survival. TXE and VAD did not show any direct inhibitory effects on the HIV-I RT enzymatic activity. Treatment of these two extracts during the infection significantly blocked infection of the reporter virus. However, pre-treatment of the reporter virus with the extracts and treatment of the extracts post-infection had little effects on the infectivity or gene expression of the reporter virus.

Conclusion: These results demonstrate that TXE and VAD inhibit HIV-I replication likely by blocking HIV-I interaction with target cells, i.e., the interaction between gp I 20 and CD4/CCR5 or gP I 20 and CD4/ CXCR4 and point to the potential of developing these two extracts to be HIV-I entry inhibitors.
} 


\section{Background}

Human immunodeficiency virus type 1 (HIV-1) causes acquired immune deficiency syndrome (AIDS) [1,2]. CD4+ T lymphocytes are the natural target of HIV-1 infection [3]. At the cellular level, HIV-1 life cycle begins with binding of HIV-1 gp120 to cellular receptors CD4 and chemokine receptors CCR5 or CXCR4 that are expressed on the surface of HIV-1 target cells, followed by gp 41 conformational change, which in turn leads to virus-cell membrane fusion and entry of the viral core (nucleocapsid) into the cytoplasm [4-6]. The virion core undergoes uncoating, the viral RNA genome is converted into proviral DNA by the virally encoded enzyme reverse transcriptase (RT) [7]. The DNA enters the nucleus and is covalently integrated into the genome of the host cell by the second virally encoded enzyme integrase (IN) [8-10]. The integrated viral DNA serves as the template for viral transcription and synthesis of various components of progeny viruses [7]. Progeny viruses are assembled on and budded through the plasma $[11,12]$. As a result, the progeny viruses become encapsulated by a layer of membrane that also harbors the viral envelope glycoproteins [6]. Concomitant with budding, a third virally encoded enzyme protease (PR) processes the core proteins into their final forms, and the virion undergoes a morphologic change known as maturation $[7,13]$. This final step primes the progeny viruses for the next round of infection.

In parallel with these progresses made in our understanding of basic HIV-1 virology and pathogenesis is development of anti-HIV-1 therapeutics. The primary targets for anti-HIV-1 therapeutic development have been two virally encoded enzymes: RT and PR. The Food and Drug Administration (FDA) has approved a total of 21 anti-HIV-1 drugs, a majority of these drugs are HIV-1 RT and PR inhibitors. Various combinations of these inhibitors, socalled highly active anti-retroviral therapy (HAART) is very effective in suppressing viral replication and has led to a significant reduction in the mortality rate of the disease, increase in the lifespan of HIV/AIDS patients and improvement of the quality of life of these patients [1416]. However, issues such as viral reservoirs, drug resistance, high dosages and frequencies, and high cost, have led to a significant crisis in the management of HIV/AIDS patients, particularly in developing nations, where there is the greatest need [17-19]. It has become evident that HAART does not offer a complete solution to the problem. Meanwhile, relatively fewer anti-HIV-1 therapeutics have been developed to target other steps of HIV-1 life cycle including entry, fusion, and integration. On the other hand, recent trials on anti-HIV-1 vaccines and microbicides have shown that some of current vaccine and microbicide strategies not only did not prevent but actually increased HIV-1 infection and transmission risks [20-23]. Therefore, additional and alternative anti-HIV-1 therapeutic strategies are desperately needed to be explored and developed to fight this virus from destroying the immune system of infected individuals and from spreading the virus to others.

In the current study, we investigated a panel of traditional Chinese medicinal herbal extracts obtained from plants in Hainan Island, China, a geographically unique tropical/ subtropical region for their activities against HIV-1 replication. We demonstrate that extracts from Euphorbiaceae, Trigonostema xyphophylloides (TXE) and Dipterocarpaceae, Vatica astrotricha (VAD) both block HIV-1 replication at the entry step. These results point to the potential of developing these plant extracts as anti-HIV-1 entry inhibitors.

\section{Methods}

\section{Preparation of plant extracts}

All plants used in this study were collected at national tropical forest parks in Hainan island, the People's Republic of China (P.R. China) including Jianfengling, Bawangling, or Mt. Diaoluo (Table 1). Scientific names and classification of these plants were validated by Prof. Qiongxin Zhong, a plant taxonomist at Department of Biology Hainan Normal University, Haikou, P. R. China. Samples of these plants were kept at the Hainan Provin-

Table I: Tropical plants selected to make extracts for anti-HIV screening

\begin{tabular}{|c|c|c|c|}
\hline Plant (family, species) & Sampling location & Sampling parts & Medicinal usage \\
\hline Euphorbiaceae, Antidesma ghaesembilla & Mt. Diaoluo & Stem & Vascuodilation \\
\hline Euphorbiaceae, Alchoornea rugosa & Jianfengling & Stem & Rash \\
\hline Euphorbiaceae, Alchoornea rugosa & Jianfengling & Leaves & Rash \\
\hline Euphorbiaceae, Trigonostema xyphophylloides & Jianfengling & Stem & Asthma \\
\hline Euphorbiaceae, Trigonostema xyphophylloides & Jianfengling & Leaves & Asthma \\
\hline Euphorbiaceae, Mallotus furetianus & Mt. Diaoluo & Stem & Fever \\
\hline Euphorbiaceae, Mallotus furetianus & Mt. Diaoluo & Leaves & Fever \\
\hline Euphorbiaceae, Sapium insigne Benth. Et Hook & Bawangling & Leaves & Snake bite \\
\hline Clavicipitaceae, Cordyceps inensis Sacc & Haikou city & Root & TB, cough, sweating \\
\hline Rubiaceae, Saprosma hainanense Merr & Bawangling & Stem & Bactericidal \\
\hline Guttiferae, Calophyllum membranaceum & Bawangling & Stem & Arthritis, pain \\
\hline Dipterocarpaceae, Vatica astrotricha & Bawangling & Leaves & Bactericidal, hepatitis \\
\hline Dipterocarpaceae, Vatica astrotricha & Bawangling & Stem & Bactericidal, hepatitis \\
\hline
\end{tabular}


cial Key Laboratory of Tropical Pharmaceutical Herbal Chemistry, Haikou, P. R. China. Plant samples were first air dried, grinded and continued to be dried in a pressurized oven at $40^{\circ} \mathrm{C}$ and $0.08 \mathrm{MPa}$. The dried and grinded materials were then subjected to 3 rounds of refluxing extraction in $75 \%$ ethanol at $80^{\circ} \mathrm{C}$. The ethanol extracts were then concentrated to become ointment in a revolving depressurized vacuum evaporator at $55^{\circ} \mathrm{C}$. The ointment was further lyophilized to the final form of powder and stored at a desiccator. The powders were dissolved in dimethyl sulfoxide (DMSO) at a concentration of 100 $\mathrm{mg} / \mathrm{ml}$ with gentle shaking overnight at room temperature. Then, the mixtures were removed of any remaining undissolved substances by centrifugation at 3,000 rpm for $10 \mathrm{~min}$ followed by filtration through a $0.4 \mu \mathrm{m}$ syringe filter. The cleared ones were used in all experiments.

\section{Cells, HIV-I HXBc2 viruses and chemicals}

Jurkat cells were purchased from American Tissue Culture Collection (ATCC, Manassas, VA) and cultured in RPMI 1640 medium supplemented with $10 \%$ fetal bovine serum, $100 \mathrm{units} / \mathrm{ml}$ penicillin, and $100 \mu \mathrm{g} / \mathrm{ml}$ streptomycin sulfate. U87.CD4.CXCR4 and U87.CD4.CCR5 cells expressing CD4/CXCR4 and CD4/CCR5 respectively were obtained from the NIH AIDS Reagent Program [24] and cultured in DMEM medium supplemented with $10 \%$ fetal bovine serum, 100 units $/ \mathrm{ml}$ penicillin, and $100 \mu \mathrm{g} / \mathrm{ml}$ streptomycin sulfate. Proviral DNA of T-tropic HIV-1 strain $\mathrm{HXBC} 2$ was transfected into Jurkat cells to generate viral inoculums by the DEAE-Dextran method. HIV-1 HXBc2 expresses HIV-1 Eli strain nef and all other HXB2 genes. Unless stated otherwise, all chemicals were from Sigma (St. Louis, MO).

\section{HIV-I replication assay}

One million Jurkat cells in $1 \mathrm{ml}$ culture medium were infected with HIV-1 corresponding to a 10,000 cpm RT activity. At twenty-four hr post-infection, cells were treated with plant extracts at indicated concentrations or equivalent concentrations of the DMSO solvent. Fresh extracts as well as DMSO were added every other day. Meanwhile, the culture supernatants were collected for the RT activity assay. Briefly, $1 \mathrm{ml}$ of the culture supernatant was collected and cleared to remove any cells and cell debris by centrifugation at $1,000 \mathrm{~g}$ for $5 \mathrm{~min}$, followed by filtration of the cleared supernatants through a $0.2 \mu \mathrm{m}$ syringe filter. Virions in the supernatant were pelleted by centrifugation at $12,000 \mathrm{~g}$ for $1 \mathrm{hr}$ and the RT activity was determined as described $[25,26]$.

\section{Cytotoxicity and syncytia formation}

The cytotoxicity of the plant extracts was determined using the trypan blue exclusion method. Briefly, Jurkat cells that were exposed to plant extracts in the presence or absence of HIV-1 infection for various lengths of time were stained in $0.2 \%$ trypan blue dye and then counted for viable cells under a light microscope. HIV-1-infected Jurkat cells were scored for syncytia formation from 4 random fields from each of the triplicate samples over the course of HIV-1 infection by a light microscope.

\section{Preparation and infection of HIV-I pseudotyped viruses}

HIV-1 viruses pseudotyped with different envelope proteins were prepared as previously described $[27,28]$. Briefly, 293T cells $\left(2 \times 10^{6}\right.$ cells per $10-\mathrm{cm}$ plate $)$ were transfected with $20 \mu \mathrm{g}$ of HIV-Luc plasmid and $4 \mu \mathrm{g}$ of pHXB2-env, p89.6-env, pVSV-G, or pcDNA3 by the calcium phosphate precipitation method. Cell culture supernatants were collected $48 \mathrm{hr}$ after medium change, filtered, and saved as virus stocks. For infection, pseudotyped viruses corresponding to a 2,000 cpm RT activity were used to infect target cells. Following $2 \mathrm{hr}$ infection, the cells were removed of remaining viruses by multiple washes with fresh medium. The cells were continued to incubate for $48 \mathrm{hr}$ and then harvested for the Luc activity assay as described $[27,28]$.

\section{Fractionation of crude extracts of TXE and VAD}

TXE and VAD extracts obtained above were suspended in $1.5 \mathrm{~L} \mathrm{H}_{2} \mathrm{O}$ and partitioned successively with petroleum ether $(\mathrm{PE})(4 \times 1.5 \mathrm{~L})$, chloroform $(\mathrm{CF})(5 \times 1.5 \mathrm{~L})$, ethyl acetate $(\mathrm{EA})(5 \times 1.5 \mathrm{~L})$, and n-butanol $(\mathrm{BT})(5 \times 1.5 \mathrm{~L})$ to obtain respective subfractions. The excessive solvents were removed from these subfractions under a reduced pressure to generate ointments. The ointments were lyophilized to the powder form. These subfractions were dissolved in DMSO at a concentration of $100 \mathrm{mg} / \mathrm{ml}$ by overnight shaking on a shaker, and the undissolved materials were removed by low speed centrifugation followed by filtration through syringe filter, as described above.

\section{Data analysis}

All values expressed as mean \pm SEM, or representative of at least three independent experiments. Comparisons among groups were made using two-tailed Student's $t$-test. A $p$ value of $<0.05$ was considered statistically significant $\left({ }^{*}\right)$, and $p<0.01$ highly significant $\left({ }^{* *}\right)$.

\section{Results \\ Anti-HIV-I activity of extracts of traditional Chinese medicinal herbal plants}

Traditional Chinese Medicine (TCM) dates back to 2000 to 3000 years. Medicinal herbs are a major component of TCM. It is estimated that over 600 different herbs have been used to treat various human diseases including those caused by virus infection [29]. Hainan Island, the second largest island off the coast of China, is located in the South China Sea and in the tropics at about $18^{\circ} \mathrm{N}$ latitude. There are about 4,200 plant species, 630 of which are listed as endemic to the island and some are nearly extinct. In this study, we selected 13 medicinal herbal plant parts that have been used to treat various human diseases by local 
ethnic Chinese in Hainan Island, China (Table 1), extracted these plants with ethanol, and tested them for the anti-HIV activity. We infected CD4+ T lymphocytes Jurkat with a replication-competent T-tropic HIV-1 strain HXB2 and then monitored HIV-1 replication over a course of 2 weeks in the presence of the plant extracts at concentrations of $1,10,100 \mu \mathrm{g} / \mathrm{ml}$. We included the solvent DMSO of the extracts and an HIV-1 RT inhibitor AZT in these experiments. We repeated this initial testing three times. Compared to the untreated control or DMSO treatment, only two of these 13 extracts: one from the stem of Euphorbiaceae, Trigonostema xyphophylloides (TXE) and the other from the stem of Dipterocarpaceae, Vatica astrotricha (VAD), displayed significant inhibition of HIV-1 replication at $10 \mu \mathrm{g} / \mathrm{ml}$ or higher at day 9 post infection (dpi) (Figure 1A). As expected, the treatment control AZT inhibited HIV-1 replication. These two extracts at $1 \mu \mathrm{g} / \mathrm{ml}$ and all other extracts showed little effects on HIV-1 replication but dose-dependent anti-HIV activity at $10 \mu \mathrm{g} / \mathrm{ml}$ or higher. We also monitored cell survival of all treatments throughout the experiments by trypan blue dye staining. Compared to the untreated control, both TXE and VAD treatments showed cell growth kinetics similarly to that of DMSO and no treatment controls (Figure 1B). The decline in the number of viable cells in HIV-1-infected cells likely results from the infection-induced cell death, as the cell number began to recover from AZT treatment toward the end of the treatment. These results provide initial evidence that TXE and VAD are inhibitory to HIV-1 replication.

\section{Cytotoxicity of the extracts}

To ascertain and establish non-toxic working concentrations of the extracts, we further determined effects of these extracts on cell survival and growth kinetics in the absence of HIV-1 infection. We treated Jurkat cells with TXE or VAD at 1,10 and $100 \mu \mathrm{g} / \mathrm{ml}$ and added the fresh extract every other day and monitored cell survival and growth. We included DMSO and AZT as controls in these experiments. Jurkat cells without any treatment were also included as a control. The cell survival and growth kinetics appeared to be indistinguishable among the cells receiving no treatment, AZT $(10 \mu \mathrm{M})$, and $10 \mu \mathrm{g} / \mathrm{ml}$ TXE and VAD and its corresponding DMSO concentration, i.e., $0.1 \%$ (Figure 2). Similar results were obtained between TXE and VAD at 1 and $100 \mu \mathrm{g} / \mathrm{ml}$ and their respective solvent DMSO concentrations $1 \%$ and $0.01 \%$ (data not shown), suggesting that TXE and VAD are not toxic at a concentration up to $100 \mu \mathrm{g} / \mathrm{ml}$. Based on these results, we chose the concentration of $10 \mu \mathrm{g} / \mathrm{ml}$ for TXE and VAD extracts for all following mechanistic studies.

\section{Inhibition of HIV-I-induced syncytia formation by the extracts}

Productive HIV-1 infection of CD4+ T cells in vitro is characterized by formation of multinucleated giant cells, so- called syncytia, which likely results in CD4+ T cell depletion in HIV-1-infected subjects. We next determined effects of these two extracts on syncytia formation. We infected Jurkat cells, treated them with $10 \mu \mathrm{g} / \mathrm{ml}$ TXE or VAD, and monitored the syncytia formation in these cells over a course of 2 weeks. We also included AZT ( $5 \mu \mathrm{M})$ and DMSO $(0.1 \%)$ as controls. In addition, we also had uninfected and HIV-1-infected Jurkat cells as controls. The number of syncytia reached the highest at day 7 post infection. Compared to untreated and DMSO-treated HIV-1infected Jurkat cells, TXE, VAD and AZT treatments all showed significant reduction (Figure 3). There were few syncytia in Jurkat cells that received no HIV-1-infection. These results are in agreement with the inhibitory effects of these extracts on HIV-1 replication (Figure 1A).

\section{No inhibition of HIV-I RT activity by the extracts}

HIV-1 is a member of the retrovirus family. The most important feature of these viruses is that replication of these viruses involves conversion of their RNA viral genome to proviral DNA, which is catalyzed by a unique virally encoded enzyme called reverse transcriptase (RT). Therefore, we next determined whether the extracts directly inhibited HIV-1 RT enzymatic activity. To do so, we compared the RT enzymatic activity of HIV-1 virions in the presence and absence of the extracts. We lysed HIV-1 virions to release the RT and performed the RT activity assay in the presence of TXE and VAD $(10 \mu \mathrm{g} / \mathrm{ml})$. We also included the RT inhibitor AZT $(5 \mu \mathrm{M})$ as a control in these experiments. In addition, we also included PBS and DMSO $(0.1 \%)$ as the solvent controls for AZT and TXE and VAD, respectively. The RT reaction without any HIV1 virions was used as an assay blank control. As expected, AZT potently inhibited HIV-1 RT activity. However, inclusion of TXE and VAD in the RT reaction did not show any significance difference in the RT activity from the PBS and DMSO control (Figure 4). These results imply that TXE and VAD-induced inhibition of HIV-1 replication is not due to their effects on the RT activity but on other steps of HIV life cycle.

\section{Block of HIV-I entry by these extracts}

HIV-1 infection begins with HIV-1 envelope gp120 binding to CD4 and chemokine co-receptors CCR5 (for Mtropic strains) or CXCR4 (for T-tropic strains) on the cell surface of HIV-1 target cells. Thus, we next determined whether the extracts had any effects on HIV-1 entry. To achieve this, we took advantage of the replication-defective single round HIV-Luc reporter system [30]. The replication-defective HIV-Luc reporter system has the HIV-1 $e n v$ gene inactivated and the firefly luciferase (Luc) gene in place of HIV-1 nef. Such a design allows in trans complementation of any viral envelope proteins including HIV-1 envelope proteins and one single round viral infection to accurately determine HIV-1 entry by the sensitive Luc activity assay. We prepared HIV-Luc reporter viruses pseu- 


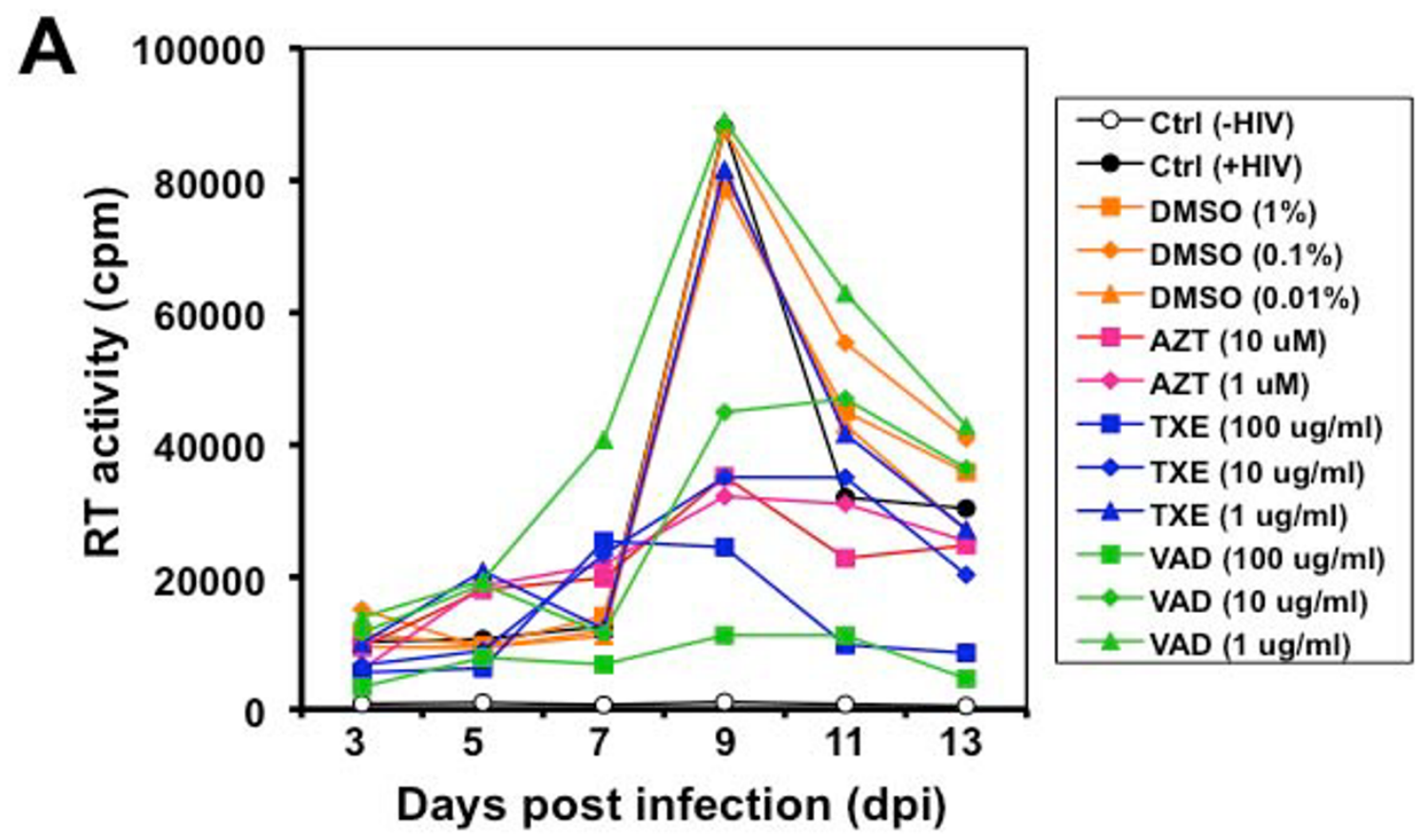

B

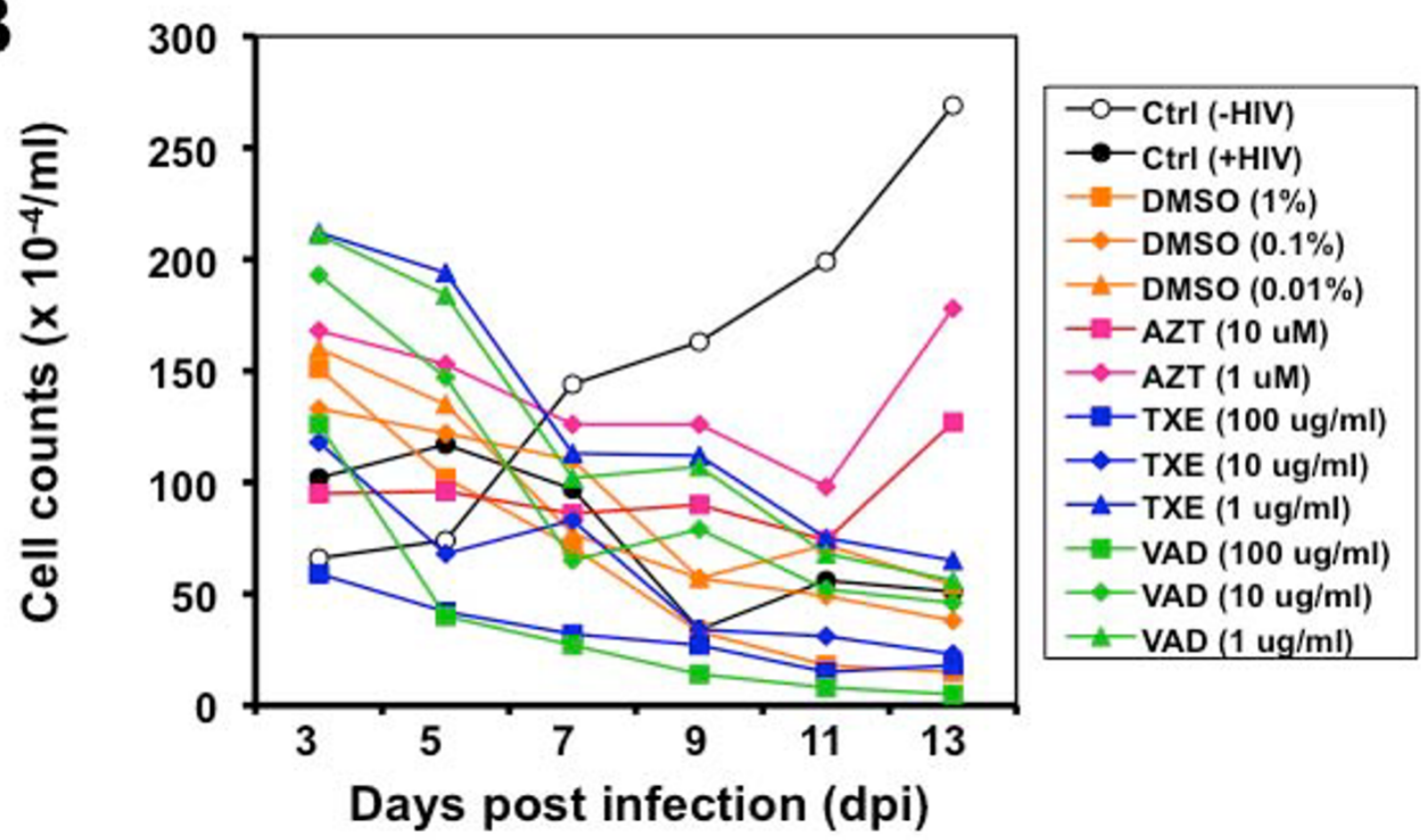

Figure I

Effects of the extracts from TXE and VAD on HIV replication and cell survival. Jurkat cells were infected with HIVI HXB2 and then exposed to the extracts $24 \mathrm{hr}$ post infection. Fresh extracts were added every other day. Meanwhile, culture supernatants were collected for the RT activity assay (A), and aliquots of cells were stained with trypan blue dye and counted for viable cells (B). DMSO was the solvent of the extracts and included as a negative control, while AZT was included as a positive control. In addition, Jurkat cells without HIV infection [Ctrl, (-HIV)] and Jurkat cells with HIV infection but without any treatments [Ctrl, (+HIV)] were also included. These data were representative of three independent experiments. 


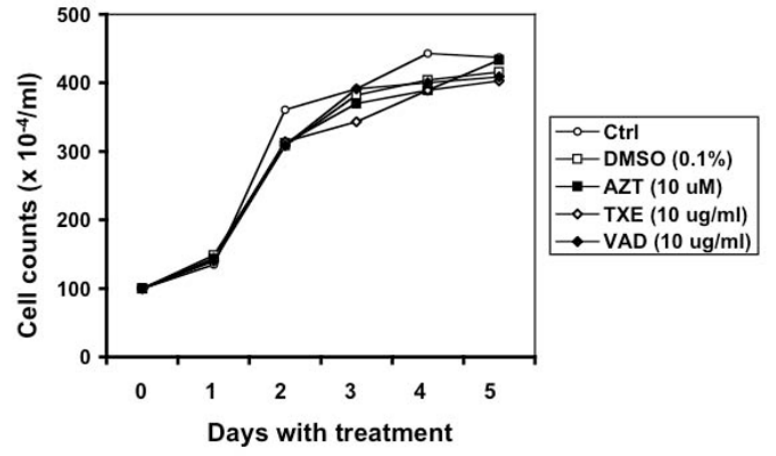

Figure 2

Effects of the extracts on cell proliferation and survival. Jurkat cells were exposed to the extracts for various lengths of time as indicated. Fresh extracts were added every other day. Cells without any treatments, treated with DMSO, or AZT were included as controls. Viable cells were determined using the trypan blue dye staining. These data were representative of three independent experiments.

dotyped with T-tropic HIV-1 HXB2 envelope. To determine effects of these extracts on HIV-1 entry, we preincubated U87.CD4.CXCR4 cells with these extracts at 10 $\mu \mathrm{g} / \mathrm{ml}$ and then infected these cells with these viruses. We then determined the Luc activity of these cells. We also

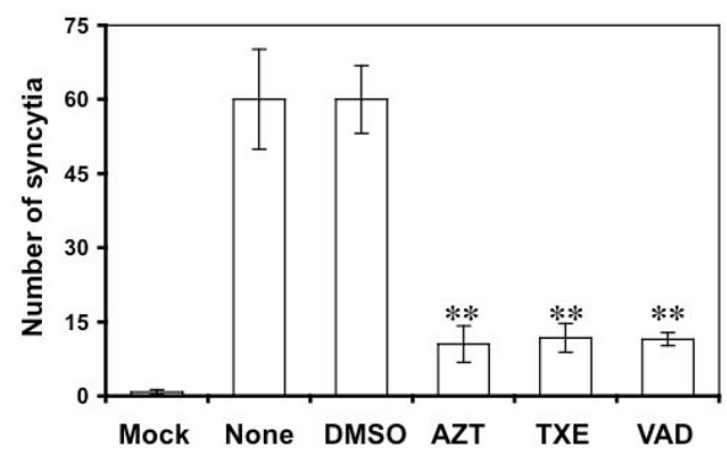

\section{Figure 3}

Effect of the extracts on syncytia formation in HIV-Iinfected Jurkat cells. Jurkat cells were infected with HIV-I and then exposed to the extracts at $10 \mu \mathrm{g} / \mathrm{ml}, 0.1 \%$ DMSO, or $5 \mu \mathrm{M}$ AZT. Syncytia in each of these treatments were counted from 4 random fields from each one of the triplicate samples under a light microscope over the course of 2 weeks infection. The data represented the number of syncytia at day 7 post infection when the maximal number of syncytia was recorded in the infections receiving no treatments (None) or DMSO. Jurkat cells without HIV-I infection were included as a control (Mock). The data were mean \pm SEM of triplicate experiments.

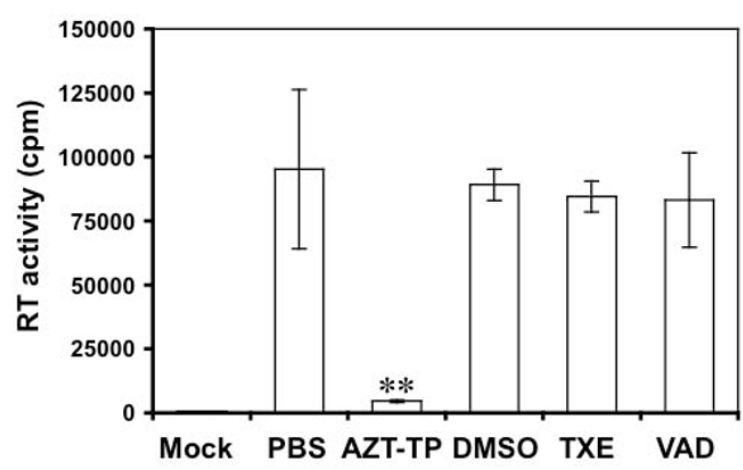

\section{Figure 4}

Direct effects of the extracts on the RT activity. HIV-I virions were assayed for their RT activity in the presence of the extracts at $10 \mu \mathrm{g} / \mathrm{ml}$. AZT-TP $(5 \mu \mathrm{M})$ was included as a positive control. DMSO (0.1\%) and phosphate-buffered saline (PBS) were included as the solvent control for the extracts and AZT, respectively. The RT reaction without any input HIV-I virions was also included as an assay control. The data were mean \pm SEM of triplicate experiments.

prepared HIV-Luc reporter viruses pseudotyped with vascular stomatitis virus envelope glycoprotein (VSV-G) or HIV-Luc viruses without any viral envelopes, which were positive and negative controls, respectively, in these experiments. We also included DMSO $(0.1 \%)$ as the solvent control for these extracts. Compared to the DMSO control, pre-incubation of U87.CD4.CXCR4 with TXE almost completely blocked infection of HIV-Luc pseudotyped with HIV-1 HXB2 envelope but had no effects on that of HIV-Luc pseudotyped with VSV-G (Figure 5A). Similar results were obtained with VAD extract (Figure 5B). These results led us to conclude that TXE and VAD inhibited HIV-1 replication through their block in HIV-1 entry to target cells.

\section{No effects of the extracts on HIV-I itself and HIV-I post- entry}

To further ascertain that TXE and VAD inhibited HIV-1 replication at the entry step and to determine whether TXE and VAD directly inactivated HIV-1 and had any effects at other steps of HIV-1 life cycle, we took advantage of the same replication-defective single round HIV-Luc reporter system but with a modified experimental scheme. We first incubated the same amount of HIV-Luc viruses pseudotyped with HXB2 envelope in $10 \mu \mathrm{g} / \mathrm{ml}$ TXE, VAD, or $0.1 \%$ DMSO at $37^{\circ} \mathrm{C}$ for $2 \mathrm{hr}$. We then recovered the viruses by centrifugation and used them to infect U87.CD4.CXCR4 cells. We cultured the cells for $48 \mathrm{hr}$ before we harvested them for the Luc activity assay. The Luc activity showed no significant difference in the viral 

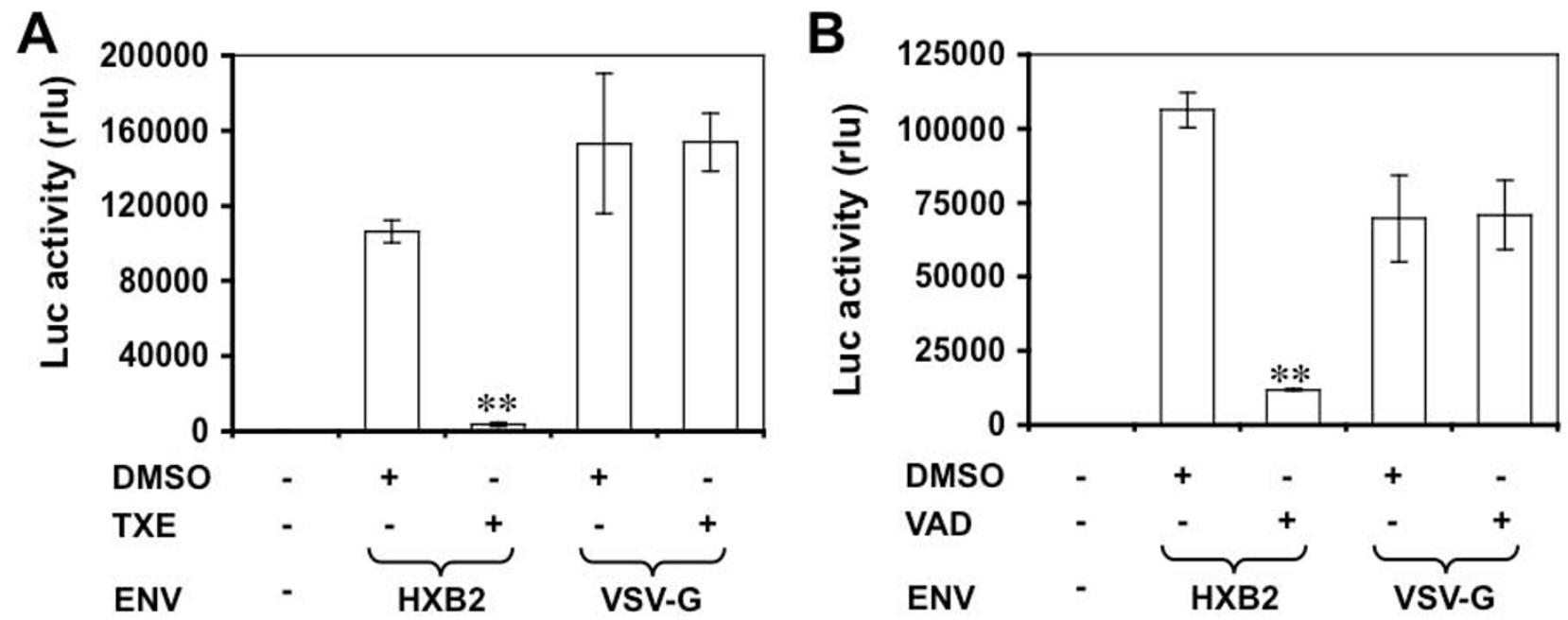

\section{Figure 5}

Effects of the extracts on HIV-I entry. U87.CD4.CXCR4 cells were treated with TXE (A) or VAD (B) at a concentration of $10 \mu \mathrm{g} / \mathrm{ml}$ for $30 \mathrm{~min}$ and then infected with HIV-Luc viruses pseudotyped T-tropic HIV-I HXB2 envelope (HXB2) or without envelope (-) for $2 \mathrm{hr}$. Forty-eight hours post infection, cells were harvested for the Luc activity assay. HIV-Luc viruses pseudotyped with VSV-G envelope (VSV-G) were included as a control. DMSO (0.1\%) was also included as a solvent control for the extracts. The data were mean \pm SEM of triplicate experiments.

infectivity between DMSO treatment control and TXE or VAD treatment, while heat-inactivated viruses had little infectivity (Figure 6A). Next, we first infected U87.CD4.CXCR4 cells with HIV-Luc viruses pseudotyped with HIV-1 HXB2 envelope at $37^{\circ} \mathrm{C}$ for $2 \mathrm{hr}$. We then removed the remaining input viruses by repeated washes with fresh medium and cultured these cells for $48 \mathrm{hr}$ in the presence of these extracts $(10 \mu \mathrm{g} / \mathrm{ml})$ or $5 \mu \mathrm{M} \mathrm{AZT}$. We then harvested the cells for the Luc activity assay. Compared to the AZT control, TXE and VAD treatment did not show any differences in the Luc activity of HIV-infected cells from the DMSO treatment (Figure 6B). Taken together, these results show that the observed inhibition of TRX and VAD on HIV-1 replication is not due to inactivation of HIV-1 by these extracts or the blockage at the post-entry step, further supporting our conclusion that TRE and VAD inhibit HIV-1 replication at the entry step of the viral life cycle.

\section{Effect of TXE or VAD on entry of primary HIV-I isolate $\mathbf{8 9 . 6}$ into cells}

Next, we extended our experiments to the dual tropic primary HIV-1 isolate 89.6 [31] to investigate whether TXE and VAD were also capable of blocking this virus from entering into its target cells. To this end, we treated U87.CD4.CXCR4 and U87.CD4.CCR5 cells were treated with $10 \mu \mathrm{g} / \mathrm{ml}$ of TXE or VAD, and then infected the cells with HIV-Luc viruses pseudotyped with HIV-1 89.6 envelope and performed the Luc activity assay. Compared to the DMSO treatment control, both TXE and VAD treatment showed significant lower Luc activities in both U87.CD4.CXCR4 and U87.CD4.CCR5 cells (Figure 7A), indicating that they blocked HIV-1 89.6 infection. In addition, we also determined effects of the extracts on HIV-1 89.6 itself and at the post-entry step. Similarly to HXB2 viruses, 89.6 viruses did not show any changes in their infectivity when they were exposed to the extracts prior to the infection (Figure $7 \mathrm{~B}$ ) and in their post-entry replication when 89.6 infection occurred prior to the extract treatment (Figure $7 \mathrm{C}$ ). Furthermore, these extracts did not have any direct inhibitory effects on the RT enzymatic activity of the HIV-1 89.6 viruses (Figure 7D). Taken together, these data demonstrate that TXE and VAD both also possessed the similar activity to block entry of primary HIV-1 isolate 89.6.

\section{Identification of anti-HIV components of TXE and VAD}

As part of further characterization of the anti-HIV activity of these two crude extracts, we next partitioned them into four subfractions using organic solvents of different hydrophobicity and polarity, that is, petroleum ether (PE), chloroform (CF), ethyl acetate (EA) and n-butanol (BT). We then determined the effects of these subfractions on HIV-1 replication. As showed above, TXE treatment 

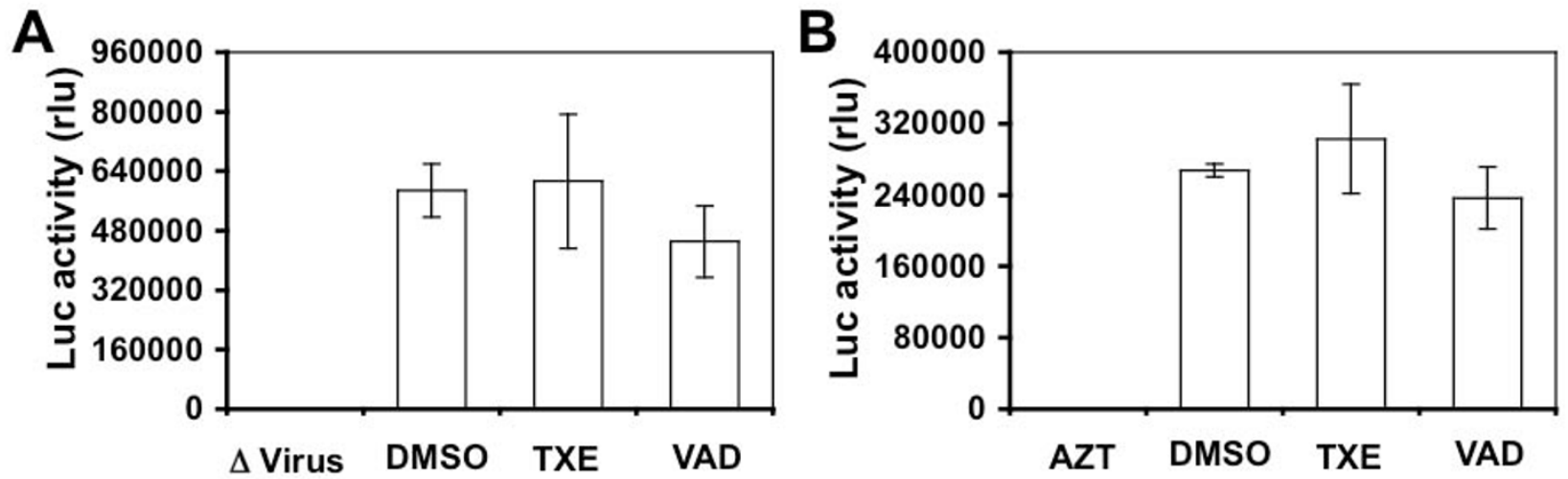

\section{Figure 6}

Effects of the extracts on HIV-I and HIV-I gene expression. A. HIV-Luc viruses pseudotyped T-tropic HIV-I HXB2 envelope (HXB2) were incubated with $10 \mu \mathrm{g} / \mathrm{ml}$ extracts for $2 \mathrm{hr}$ and then used to infect U87.CD4.CXCR4 cells. Cells were harvested $48 \mathrm{hr}$ for the Luc activity assay $48 \mathrm{hr}$ after infection. Infection with heat-inactivated HIV-Luc/HXB2 viruses ( $\triangle$ Virus) was included as the control. B. U87.CD4.CXCR4 cells were infected with HIV-Luc viruses pseudotyped T-tropic HIV-I HXB2 envelope (HXB2) or without envelope (-) for $2 \mathrm{hr}$ and then removed of the remaining input viruses by repeated washes with fresh medium. Then, the infected cells were cultured for $48 \mathrm{hr}$ in the presence of the extracts $(\mathrm{I} 0 \mu \mathrm{g} / \mathrm{ml})$ and then harvested for the Luc activity assay. DMSO $(0.1 \%)$ was also included as a solvent control for the extracts, while $0.5 \mu \mathrm{M}$ AZT was included as a positive control. The data were mean \pm SEM of triplicate experiments.

inhibited HIV-1 replication in a highly significant fashion (Figure 8A). Compared to the DMSO-treated control, HIV replication was significantly lower in cells treated with $\mathrm{CF}$ and BU subfractions, while HIV replication showed little changes in cells treated with its PE and EA subfractions. In contrast, the PE, CF, and EA subfractions of the VAD extract had highly significantly lower HIV-1 replication than the DMSO control, while its BT subfraction displayed no anti-HIV activity (Figure $8 \mathrm{~B}$ ). Similar results were obtained from the single-round infection assay (data not shown). These results suggest that the active anti-HIV components can be further isolated from both TXE and VAD extracts and may differ between these two extracts.

\section{Discussion}

Using a well-established HIV-1 replication system, we screened extracts of traditional Chinese medicinal herbal plants for their anti-HIV activities (Table 1). We showed that extracts from the stem of Euphorbiaceae, Trigonostema xyphophylloides (TXE) and the stem of Dipterocarpaceae, Vatica astrotricha (VAD) inhibited HIV-1 replication without apparent effects on cell proliferation and cell survival (Figure 1 and Figure 2). The inhibitory effects of these two extracts were further corroborated by the finding that these extracts prevented HIV-infected cells from forming syncytia (Figure 3). Nevertheless, we did not detect any effects of these extracts on HIV-1 RT enzymatic activity (Figure 4). Instead, we showed that these extracts potently blocked HIV-1 from entering its target cells (Figure 5).
Furthermore, we showed that these extracts had little effects on post-entry HIV-1 gene expression (Figure 6). We obtained similar results with the primary isolate, HIV-1 89.6 which displays dual tropism, using both CXCR4 and CCR5 for entry into cells (Figure 7). Taken together, these studies revealed the anti-HIV activities of these two plant extracts and suggest that their anti-HIV activity results from interfering with HIV-1 entry.

All currently FDA-approved anti-HIV drugs are chemically synthesized [32,33]. Development of these drugs involves an extremely long cycle of research, design and optimization, thus these drugs are very expensive. Besides, as many of these drugs are structural analogs of host metabolic components, use of these drugs is often limited by sideeffects and non-adherence issues. In contrast, medicines of natural origins such as herbs have a much short development cycle and relatively inexpensive. Importantly, the toxicity of nature-derived medications is rarely an issue. A recent study has shown that more than two third of those who are on anti-HIV medications are also taking alternative therapy, including nearly $25 \%$ on those derived from botanicals and Chinese herbs [34,35]. There is clearly a need to further investigate and develop this alternative anti-HIV therapy, as it likely makes the anti-HIV therapy ultimately affordable and available to all HIV/AIDSaffected individuals including those in developing and under-developed countries. 
A

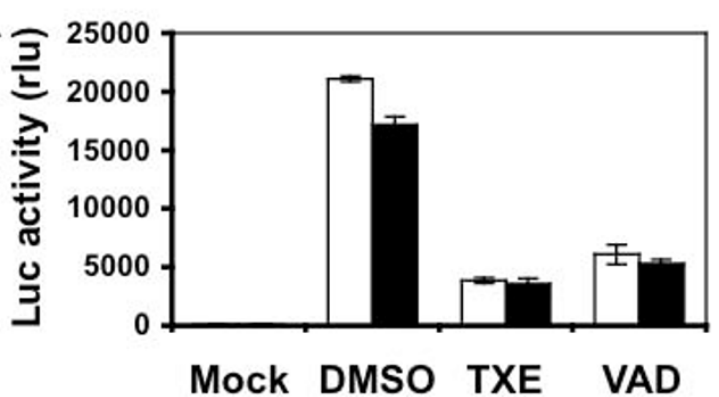

C

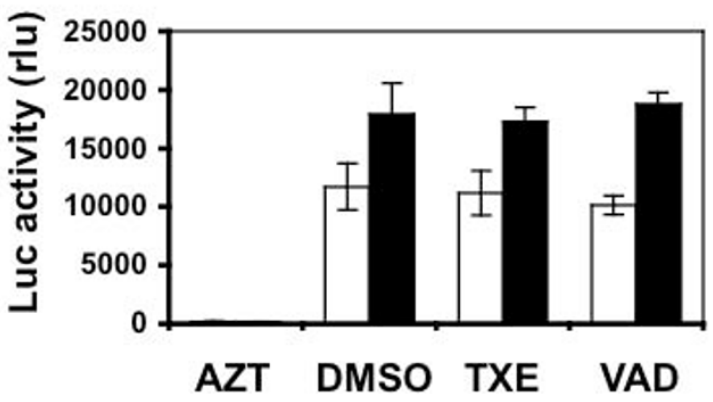

B

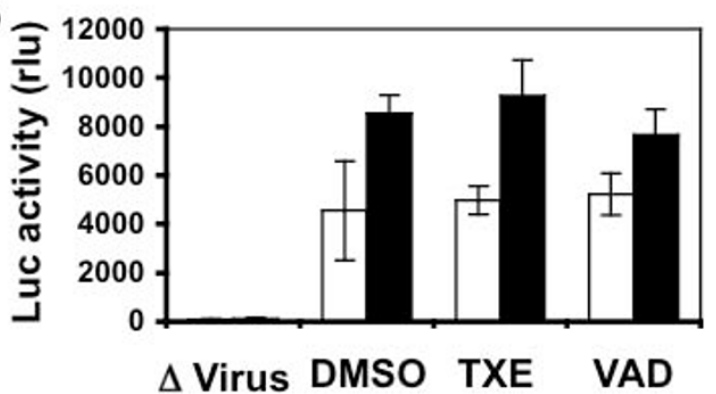

D

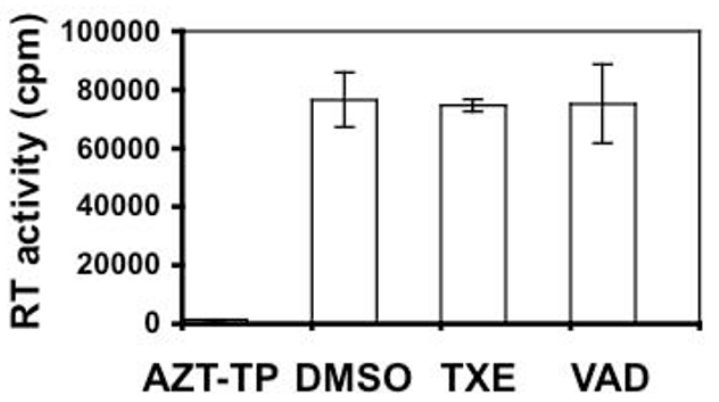

Figure 7

Effects of the extracts on primary HIV-I isolate 89.6. A. U87.CD4.CXCR4 and U87.CD4.CCR5 cells were first treated with $10 \mu \mathrm{g} / \mathrm{ml}$ extracts and then infected with HIV-Luc viruses pseudotyped with 89.6 envelope. Infection of HIV-Luc viruses without an envelope was included as the mock infection control. B. HIV-Luc viruses pseudotyped 89.6 envelope were first incubated with $10 \mu \mathrm{g} / \mathrm{ml}$ extracts and then used to infect U87.CD4.CXCR4 and U87.CD4.CCR5 cells. Infection with heat-inactivated HIV-Luc/89.6 viruses ( $\Delta$ Virus) was included as the control. C. U87.CD4.CXCR4 and U87.CD4.CCR5 were first infected with HIV-Luc viruses pseudotyped with 89.6 envelope and then treated with $10 \mu \mathrm{g} / \mathrm{ml}$ extracts or $5 \mu \mathrm{M}$ AZT. A-C: open bar for U87.CD4.CXCR4 cells; closed bar for U87.CD4.CCR5 cells. D. HIV-Luc viruses pseudotyped with 89.6 envelope were directly treated with $10 \mu \mathrm{g} / \mathrm{ml}$ extracts or $5 \mu \mathrm{M}$ AZT-TP, the RT activity was determined. The data were mean \pm SEM of triplicate experiments.

Some efforts have been made to identify natural remedies to combat HIV/AIDS in clinical settings. A number of natural products have been shown to possess anti-HIV-1 activities, including those derived from microorganisms, marine organisms, and plants, and these natural products inhibit HIV-1 replication at various steps of HIV-1 life cycle [36]. Currently, more than 150 natural products have been isolated from marine organisms to show promising anti-HIV-1 activity $[37,38]$. One of the outstanding examples is cyanovirin-N, an $11 \mathrm{KDa}$ anti-HIV-1 protein that was initially isolated from the cyanobacterium (bluegreen alga) Nostoc ellipsosporum [39]. Cyanovirin-N inhibits HIV-1 replication through its vivid binding to HIV-1 gp120 and as a result, inactivates the viruses and blocks the fusion of viruses to the cell membrane [40,41]. The protein is now in Phase II clinical trial to be used as an anti-HIV-1 microbicide.
Traditional Chinese Medicines (TCMs) have a very long history. They have been used to treat various human diseases and regarded as the state cultural treasure by the Chinese government. Development and standardization of TCMs have recently been proposed as the top biomedical research priority for the next 5-10 years in P. R. China. Studies on the anti-HIV activities and mechanisms of TCMs are very limited and are expected to accelerate. Currently, HIV-1-inhibitory TCMs are reported to include Scutellaria baicalensis Georgi, Prunella vulgaris, Paeonia Suffruticosa, Rhizoma Polygoni Cuspidati, Radix Notoginseng, Ramulus Visci, and Ajuga Decumbens Thumb [42-47]. Our studies added Euphorbiaceae, Trigonostema xyphophylloides (TXE) and Dipterocarpaceae, Vatica astrotricha (VAD) onto this soon-to-be-rapidly-expanding list. Studies are under way to further fractionate these extracts for identification of the active anti-HIV-1 entry constitu- 

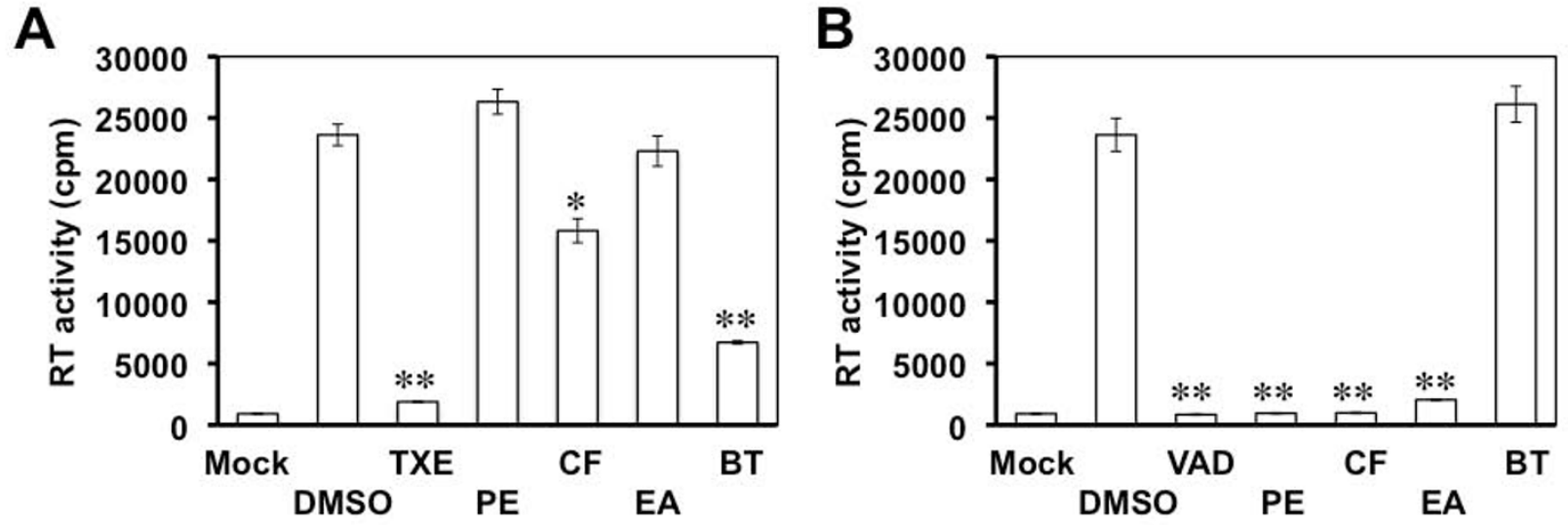

\section{Figure 8}

Anti-HIV components of TXE and VAD extracts. Jurkat cells were infected with HIV-I HXB2 and then exposed to I0 $\mu \mathrm{g} / \mathrm{ml}$ TXE (A), VAD (B), or each of its partition subfractions from petroleum ether (PE), chloroform (CF), ethyl acetate (EA) and n-butanol (BT) $24 \mathrm{hr}$ post infection. Fresh extracts or subfraction were added every other day. Meanwhile, culture supernatants were collected for the RT activity assay, and aliquots of cells were stained with trypan blue dye and counted for viable cells. DMSO was the solvent of the extracts and subfractions and included as a vehicle control. The RT data from the supernatants collected at day 9 of the peak viral replication were presented. Extracts and their subfractions showed no apparent cytotoxic effects on the cells. The data were mean \pm SEM of triplicate experiments.

ents in these extracts and for better characterization of their effects on the interaction between HIV-1 gp120 and CD4/chomine receptors CCR5 and CXCR4.

\section{Conclusion}

TXE and VAD extracts possess potent inhibitory activities against HIV-1 replication and entry of both T and M tropic HIV-1 isolates. These results suggest that TXE and VAD are potential biosources for further identification and isolation of active anti-HIV-1 constituents. Identification of these active constituents will help establish the precise mechanisms of this entry inhibition as well as standardize the extracts for potential clinical translation.

\section{List of abbreviations}

TXE: extract from Euphorbiaceae, Trigonostema xyphophylloides; VAD: extract from Dipterocarpaceae, Vatica astrotricha; TCM: traditional Chinese medicine; HIV-Luc: A HIV-1-based reporter virus containing inactive nef and env genes and having the luciferase (Luc) gene inserted at the 5 ' end nef gene; 89.6-env: envelope from HIV-1 isolate 89.6; HXB2-env: envelope from HIV-1 isolate HXB2; VSV$\mathrm{G}$ : vascular stomatitis virus envelope glycoprotein; RT: reverse transcriptase; PBS: phosphate-buffered saline; DMSO: dimethyl sulfoxide; AZT: azidothymidine; AZTTP: azidothymidine triphosphate.

\section{Competing interests}

The authors declare that they have no competing interests.

\section{Authors' contributions}

IWP, CH, GC and JJH designed, organized and coordinated the overall study, and wrote the manuscript. $\mathrm{CH}$ and GC coordinated collection and extraction of the plant samples, IWP and JJH designed the HIV-1 experiments, IWP, TW, LG and YL performed the HIV-1 experiments and acquired and analyzed the data. CH, XPS, CC, XMS, BY and GC collected the plant samples and performed extraction. All authors read and approved the final manuscript.

\section{Acknowledgements}

This work was supported in part by a grant award \#20562004 from the National Natural Science Foundation of China (to C. Han and G. Chen) and grants R2IDA022986 and R2IDA025487 (to JJH) from the National Institutes of Health.

\section{References}

I. Barre-Sinoussi F, Chermann JC, Rey F, Nugeyre MT, Chamaret S, Gruest J, Dauguet C, Axler-Blin C, Vezinet-Brun F, Rouzioux C, et al: Isolation of a T-lymphotropic retrovirus from a patient at risk for acquired immune deficiency syndrome (AIDS). Science 1983, 220:868-871.

2. Broder S, Gallo RC: A pathogenic retrovirus (HTLV-III) linked to AIDS. N Engl J Med I984, 3 I I: I 292-1297.

3. Deen KC, McDougal JS, Inacker R, Folena-Wasserman G, Arthos J, Rosenberg J, Maddon PJ, Axel R, Sweet RW: A soluble form of 
CD4 (T4) protein inhibits AIDS virus infection. Nature 1988 , $331: 82-84$

4. Eckert DM, Kim PS: Mechanisms of viral membrane fusion and its inhibition. Annu Rev Biochem 200I, 70:777-8I0.

5. Platt EJ, Durnin JP, Kabat D: Kinetic factors control efficiencies of cell entry, efficacies of entry inhibitors, and mechanisms of adaptation of human immunodeficiency virus. J Virol 2005, 79:4347-4356

6. Ray N, Doms RW: HIV-I coreceptors and their inhibitors. Curr Top Microbiol Immunol 2006, 303:97-I 20.

7. Coffin J, Hiughes S, Varmus H: Retroviruses Plainview, NY, USA: Cold Spring Harbor Laboratory Press; 1997.

8. Mitchell RS, Beitzel BF, Schroder AR, Shinn P, Chen H, Berry CC, Ecker JR, Bushman FD: Retroviral DNA integration: ASLV, HIV, and MLV show distinct target site preferences. PLoS Biol 2004, 2:E234.

9. Scherdin $U$, Rhodes $K$, Breindl M: Transcriptionally active genome regions are preferred targets for retrovirus integration. J Virol 1990, 64:907-912.

10. Schroder AR, Shinn P, Chen H, Berry C, Ecker JR, Bushman F: HIV$\mathrm{I}$ integration in the human genome favors active genes and local hotspots. Cell 2002, I 1 0:52 I-529.

II. Bieniasz PD: Late budding domains and host proteins in enveloped virus release. Virology 2006, 344:55-63.

12. Martin-Serrano J, Zang T, Bieniasz PD: Role of ESCRT-I in retroviral budding. I Virol 2003, 77:4794-4804.

13. Zhu T, Mo H, Wang N, Nam DS, Cao Y, Koup RA, Ho DD: Genotypic and phenotypic characterization of HIV-I patients with primary infection. Science 1993, 261: I I79-II8I.

14. Hogg RS, Heath KV, Yip B, Craib KJ, O'Shaughnessy MV, Schechter MT, Montaner JS: Improved survival among HIV-infected individuals following initiation of antiretroviral therapy. JAMA 1998, 279:450-454.

15. Mocroft A, Vella S, Benfield TL, Chiesi A, Miller V, Gargalianos P, d'Arminio Monforte A, Yust I, Bruun JN, Phillips AN, Lundgren JD: Changing patterns of mortality across Europe in patients infected with HIV-I. EuroSIDA Study Group. Lancet 1998, 352:1725-1730.

16. Palella FJ Jr, Delaney KM, Moorman AC, Loveless MO, Fuhrer J, Satten GA, Aschman DJ, Holmberg SD: Declining morbidity and mortality among patients with advanced human immunodeficiency virus infection. HIV Outpatient Study Investigators. N Engl J Med 1998, 338:853-860.

17. Chou R, Huffman LH, Fu R, Smits AK, Korthuis PT: Screening for HIV: a review of the evidence for the U.S. Preventive Services Task Force. Ann Intern Med 2005, I 43:55-73.

18. Hawkins T: Appearance-related side effects of HIV-I treatment. AIDS Patient Care STDS 2006, 20:6-18.

19. d'Arminio Monforte A, Lepri AC, Rezza G, Pezzotti P, Antinori A, Phillips AN, Angarano G, Colangeli V, De Luca A, Ippolito G, et al: Insights into the reasons for discontinuation of the first highly active antiretroviral therapy (HAART) regimen in a cohort of antiretroviral naive patients. I.CO.N.A. Study Group. Italian Cohort of Antiretroviral-Naive Patients. Aids 2000, I 4:499-507.

20. Fauci AS, Johnston MI, Dieffenbach CW, Burton DR, Hammer SM, Hoxie JA, Martin M, Overbaugh J, Watkins DI, Mahmoud A, Greene WC: HIV vaccine research: the way forward. Science 2008 , 321:530-532.

21. Mauck CK, Straten AV: Using Objective Markers to Assess Participant Behavior in HIV Prevention Trials of Vaginal Microbicides. J Acquir Immune Defic Syndr 2008, 49:64-9.

22. Sekaly RP: The failed HIV Merck vaccine study: a step back or a launching point for future vaccine development? J Exp Med 2008, 205:7-12.

23. Van Damme L, Govinden R, Mirembe FM, Guedou F, Solomon S, Becker ML, Pradeep BS, Krishnan AK, Alary M, Pande B, et al.: Lack of effectiveness of cellulose sulfate gel for the prevention of vaginal HIV transmission. N Engl J Med 2008, 359:463-472.

24. Bjorndal A, Deng H, Jansson M, Fiore JR, Colognesi C, Karlsson A, Albert J, Scarlatti G, Littman DR, Fenyo EM: Coreceptor usage of primary human immunodeficiency virus type $I$ isolates varies according to biological phenotype. I Virol 1997, 7I:7478-7487.

25. Li J, Liu Y, Park IW, He J]: Expression of exogenous Sam68, the 68-kilodalton SRC-associated protein in mitosis, is able to alleviate impaired Rev function in astrocytes. J Virol 2002, 76:4526-4535.

26. Liu Y, Kim BO, Kao C, Jung C, Dalton JT, He J): Tip I I 0, the human immunodeficiency virus type I (HIV-I) Tat-interacting protein of $110 \mathrm{kDa}$, is a negative regulator of androgen receptor (AR) transcription activation. J Biol Chem 2004, 279:21 766-73.

27. He J, Chen Y, Farzan M, Choe H, Ohagen A, Gartner S, Busciglio J, Yang X, Hofmann W, Newman W, et al.: CCR3 and CCR5 are coreceptors for HIV-I infection of microglia. Nature 1997, 385:645-649.

28. Li J, Liu Y, Kim BO, He J]: Direct participation of Sam68, the 68kilodalton Src-associated protein in mitosis, in the CRMImediated Rev nuclear export pathway. J Virol 2002, 76:8374-8382.

29. Xiang YZ, Shang HC, Gao XM, Zhang BL: A comparison of the ancient use of ginseng in traditional Chinese medicine with modern pharmacological experiments and clinical trials. Phytother Res 2008, 22:85I-858.

30. He J, Landau NR: Use of a novel human immunodeficiency virus type I reporter virus expressing human placental alkaline phosphatase to detect an alternative viral receptor. J Virol 1995, 69:4587-4592.

31. Doranz BJ, Rucker J, Yi Y, Smyth RJ, Samson M, Peiper SC, Parmentier M, Collman RG, Doms RW: A dual-tropic primary HIV-I isolate that uses fusin and the beta-chemokine receptors CKR-5, CKR-3, and CKR-2b as fusion cofactors. Cell 1996, 85: II49-II 58.

32. De Clercq E: New developments in anti-HIV chemotherapy. Biochim Biophys Acta 2002, I 587:258-275.

33. De Clercq E: The design of drugs for HIV and HCV. Nat Rev Drug Discov 2007, 6:1001-1018.

34. Gore-Felton C, Vosvick M, Power R, Koopman C, Ashton E, Bachmann MH, Israelski D, Spiegel D: Alternative therapies: a common practice among men and women living with HIV. J Assoc Nurses AIDS Care 2003, I 4: 17-27.

35. Josephs JS, Fleishman JA, Gaist P, Gebo KA: Use of complementary and alternative medicines among a multistate, multisite cohort of people living with HIVIAIDS. HIV Med 2007, 8:300-305.

36. De Clercq E: Current lead natural products for the chemotherapy of human immunodeficiency virus (HIV) infection. Med Res Rev 2000, 20:323-349.

37. Gochfeld DJ, El Sayed KA, Yousaf M, Hu JF, Bartyzel P, Dunbar DC, Wilkins SP, Zjawiony JK, Schinazi RF, Schlueter Wirtz S, et al:: Marine natural products as lead anti-HIV agents. Mini Rev Med Chem 2003, 3:40I-424.

38. Tziveleka LA, Vagias C, Roussis V: Natural products with antiHIV activity from marine organisms. Curr Top Med Chem 2003, 3:1512-1535

39. Gustafson KR, Sowder RC 2nd, Henderson LE, Cardellina JH 2nd, McMahon JB, Rajamani U, Pannell LK, Boyd MR: Isolation, primary sequence determination, and disulfide bond structure of cyanovirin-N, an anti-HIV (human immunodeficiency virus) protein from the cyanobacterium Nostoc ellipsosporum. Biochem Biophys Res Commun 1997, 238:223-228.

40. Dey B, Lerner DL, Lusso P, Boyd MR, Elder JH, Berger EA: Multiple antiviral activities of cyanovirin-N: blocking of human immunodeficiency virus type I gp I 20 interaction with CD4 and coreceptor and inhibition of diverse enveloped viruses. J Virol 2000, 74:4562-4569.

4I. Esser MT, Mori T, Mondor I, Sattentau QJ, Dey B, Berger EA, Boyd $M R$, Lifson JD: Cyanovirin-N binds to gp I 20 to interfere with CD4-dependent human immunodeficiency virus type I virion binding, fusion, and infectivity but does not affect the CD4 binding site on gp I 20 or soluble CD4-induced conformational changes in gp I 20. J Virol I999, 73:4360-437I.

42. Au TK, Lam TL, Ng TB, Fong WP, Wan DC: A comparison of HIV$I$ integrase inhibition by aqueous and methanol extracts of Chinese medicinal herbs. Life Sci 200I, 68:1687-1694.

43. Del Beccaro MA, Mendelman PM, Inglis AF, Richardson MA, Duncan NO, Clausen CR, Stull TL: Bacteriology of acute otitis media: a new perspective. J Pediatr 1992, I 20:8I-84.

44. Liu J: The use of herbal medicines in early drug development for the treatment of HIV infections and AIDS. Expert Opin Investig Drugs 2007, 16:1355-1364. 
45. Liu S, Jiang S, Wu Z, Lv L, Zhang J, Zhu Z, Wu S: Identification of inhibitors of the HIV-I gp4I six-helix bundle formation from extracts of Chinese medicinal herbs Prunella vulgaris and Rhizoma cibotte. Life Sci 2002, 7I:|779-|79|.

46. Tang $X$, Chen $H$, Zhang $X$, Quan K, Sun M: Screening anti-HIV Chinese materia medica with HIV and equine infectious anemic virus reverse transcriptase. J Tradit Chin Med 1994, 14:10-13.

47. Wu JA, Attele AS, Zhang L, Yuan CS: Anti-HIV activity of medicinal herbs: usage and potential development. Am J Chin Med 200I, 29:69-8I.

\section{Pre-publication history}

The pre-publication history for this paper can be accessed here:

http://www.biomedcentral.com/1472-6882/9/29/prepub

Publish with Bio Med Central and every scientist can read your work free of charge

"BioMed Central will be the most significant development for disseminating the results of biomedical research in our lifetime. "

Sir Paul Nurse, Cancer Research UK

Your research papers will be:

- available free of charge to the entire biomedical community

- peer reviewed and published immediately upon acceptance

- cited in PubMed and archived on PubMed Central

- yours - you keep the copyright

Submit your manuscript here:

http://www.biomedcentral.com/info/publishing_adv.asp
BioMedcentral 